\title{
Study of Bacteriophages in Kinko Bay
}

\author{
Daiichi KaKIMOTO and Hikaru NaGATOMI \\ (Received October 20, 1971)
}

\begin{abstract}
The isolation and the purification of bacteriophages living in the coastal sea waters of Kinko Bay were studied. The characteristics of phages compared with those of host bacteria were also studied. The authors found that in order to isolate the phage from sea water, the enrichment of phages before isolation is indispensable. The characteristics of isolated phages were as follows;

1. Six bacteriophages were isolated from the sea waters of Kinko Bay.

2. Among the six host bacteria, two were halophilic and one of them was pseudomonas species, but the remaining were not classifiable according to BAIN and SHEWAN's classification. Of six isolates four species were classified as marine bacteria. According to BAIN and SHEWAN's classification, two of the marine bacteria were Pseudomonas and the other two were Vibrios. 3. As compared with host bacteria. All bacteriophages isolated demonstrated strong resistance to various agents; i.e., to chemicals, to hypotonic solutions such as diluted artificial sea water.
\end{abstract}

KRISS and RUKINA, ${ }^{1)}$ and SPENCER ${ }^{3)}$ found the presence of bacteriophages in coastal sea water. Recently CHEN et al. ${ }^{3)}$ have reported two marine bacteriophages, JOHNSON ${ }^{4)}$ has also isolated Vibrio phage from the sea water of the Indian Ocean, VALENTINE et al. ${ }^{\text {) }}$. have studied on the morphology of marine bacteriophages, and CHEN et al. ${ }^{3}$ have revealed the serological properties of marine bacteriophages. However, the reports of marine bacteriophages are comparatively scant. In general, it was presumed that several genera and species of bacteria; Micrococcus, Bacillus, and Photobacterium, served as host for bacteriophage multiplication. The authors isolated six different bacteriophages from coastal sea water of Kinko Bay in the summer of 1968, and demonstrated the morphological aspects and characteristics of both bacteriophages and host bacteria.

\section{Experimentals and Method}

Isolation of host bacteria: Prior to the isolation of bacteriophages, the candidates for host bacteria were selected from sea water. In the study, the examination was done in two stages; one was of isolation of candidates from the bacteria of sea water, and another was of enrichment of bacteriophage. The isolation and enrichment of phage by mixing culture were shown in Fig. 1. In the course of the isolation, if the lytic zone is ascertained by spotting drop of filtrate on the plate of test organism, such organism may be a candidate. To make it certain, the lytic zone was harvested with a loop, the harvest being inoculated into young culture of the bacterium supposed to be a candidate. After being incubated

* Faculty of Fisheries, Kagoshima University, 470 Shimoarata-cho, Kagoshima City (柿本大壱·永 富 光: 㢈児島大学水産学部) 


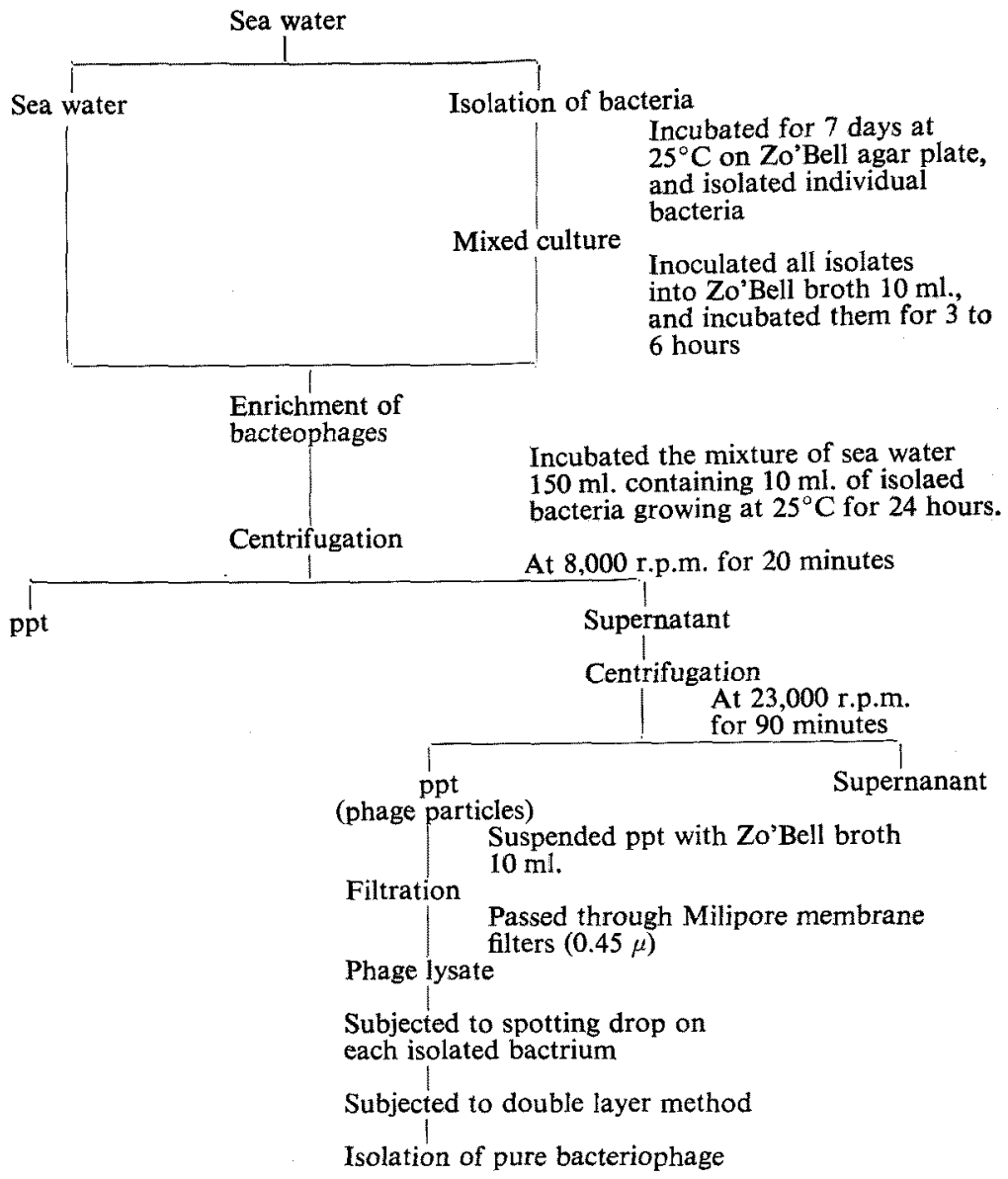

Fig. 1. Isolation and purification of bacteriophages.

for 24 hours at $25^{\circ} \mathrm{C}$, the culture was filtered through a Milipore membrane filter $(0.45 \mu)$, the filtrate being subjected to the ADAM's double layer method ${ }^{6)}$. One that the plaques were observed is certainly a host bacterium.

Isolation of bacteriophage: Isolation of bacteriophages was as follows: the lysate of each bacterium was subjected to ADAM's double layer method, and a single plaque obtainable was inoculated into a young host bacterium and incubated again for enrichment. The final isolation was carried out by filtration. The concentrated phage lysate was preserved in a cold room.

Characteristics of host bacteria and bacteriophages: Main characteristics of host bacteria were examined by usual methods, mainly according to BAIN and SHEWAN's classification $^{7)}$ of the definite genera: Aeromonas, Vibrios, and related organisms. In this study, sea water used was taken at two stations of Kinko Bay (Fig. 2). In order to ascertain the habitat of isolated bacteria, their salt requirement was examined by HIDAKA's 
method $^{8)}$.

Main characteristics of bacteriophages were examined by the method described in "The Methods in Microbiology" Vol. 3 $\mathrm{B}^{9}$, that is, filterability passed through membrane filters, respective resistances to chloroform, phenol, and formaldehyde.

In this examination, the absorption rate was assayed by common method as follows; the method is to centrifuge the mixture at 4,000 r.p.m. for one hour, so that only the bacteria, but not free phage particles, sedi-

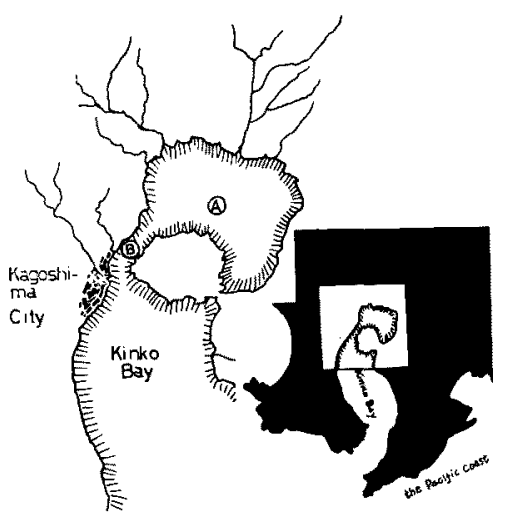

Fig. 2. Kinko Bay and two stations. ment into the pellet. The number of infective centers in pellet and supernatant fluid were assayed by the plaque count method, and the absorption rate was caluculated from these two counts.

Comparative examination of host bacteria and phages was also examined concerning the following subjects: Heat resistance, viability in dilute artificial sea water. In the former examination, $40^{\circ} \mathrm{C}, 45^{\circ} \mathrm{C}$, and $50^{\circ} \mathrm{C}$ on host bacteria, $60^{\circ} \mathrm{C}, 65^{\circ} \mathrm{C}$, and $70^{\circ} \mathrm{C}$ on bacteriophages were applied, in the latter examination, dilution ranges from 100 to 10,000 fold were used respectively.

Electron microscopic observation of bacteriophages: The observations were carried out by the Electron microscope Hitachi HU 11P. The specimens were prepared by washing twice with $1 \%$ ammonium acetate, and fixed with $2 \%$ phosphotangstate.

\section{Results and Discussion}

From the two stations of Kinko Bay (Fig. 2), six bacteriophages were isolated and purified. Fig. 3 is the views of plaques of the six bacteriophages. Brief characterizations of host bacteria were shown in Table 1, and, of bacteriophages, in Table 2.

According to BAIN and SHEwAN's classification, A-4, A-6, and B-4 were $P_{\text {seudomonas }}$ spp; B-5 and B-8 were Vibrios; and B-1 was neither Vibrio, nor Pseudomonas, because of its flagellation. The growth in the 5 definite media suggested in A-4, B-4, B-5, and B-8 were classified into marine type, while the other two were halophiles as shown in Table 2.

Characteristics of bacteriophages: Counts of phage particles decreased in all cases after being filtered through Milipore membrane filters $(0.45 \mu)$, however, the decrease of three phages A-4p, A- $6 p$, and B-8p being filtered was more sever than the other three B-1p, B-4p, and B-5p. Against the three chemicals, all bacteriophages used made considerable resistance. Formaldehyde was most toxic to all phages as compared with 

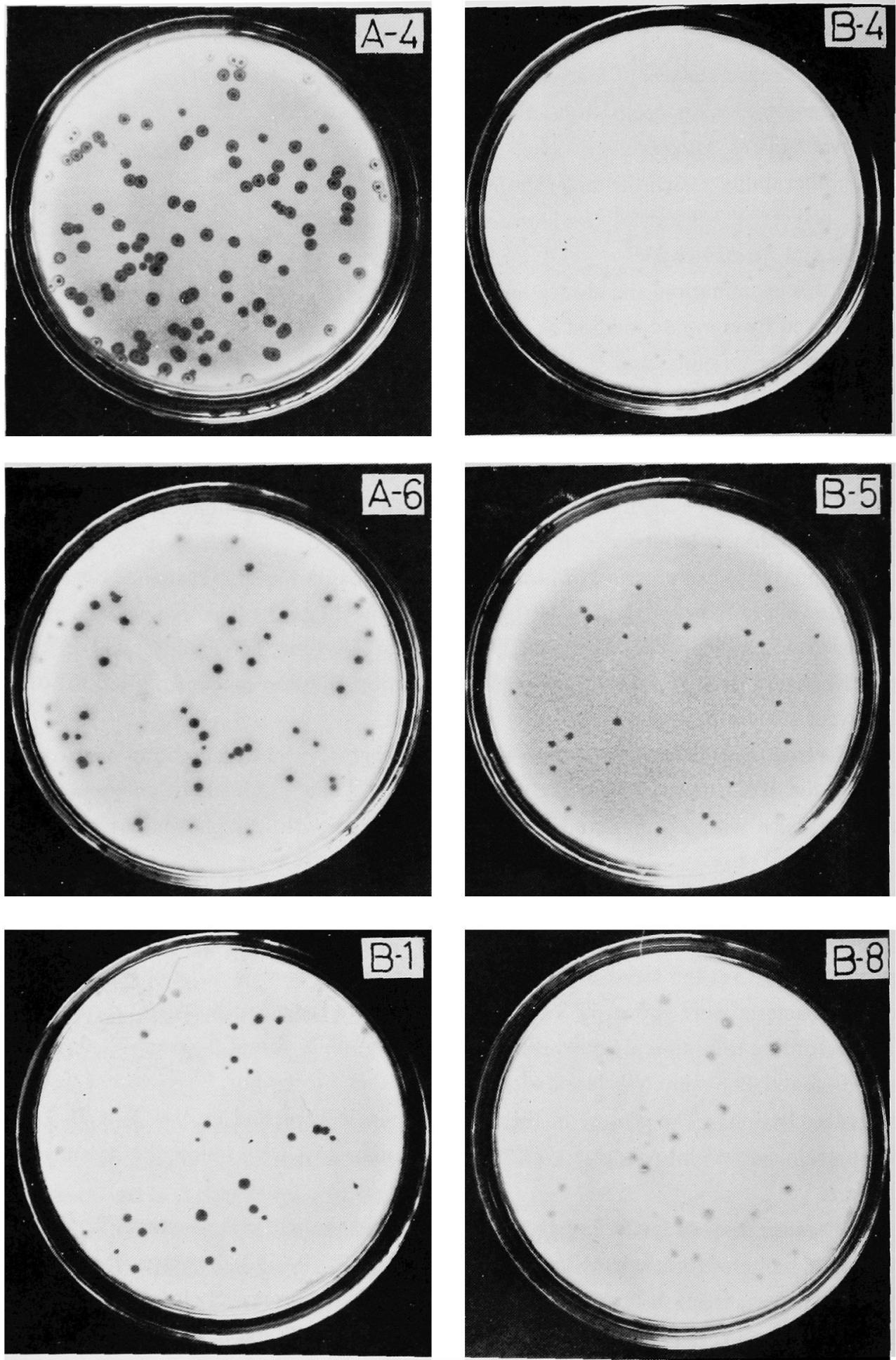

Fig. 3. Plaques of bacteriophages. 
Table 1. Main characteristics of host bacteria.

\begin{tabular}{|c|c|c|c|c|c|c|}
\hline $\begin{array}{ll} & \text { Strain } \\
\text { Character }\end{array}$ & $A-4$ & A-6 & B-1 & $\mathrm{B}-4$ & B-5 & B-8 \\
\hline Gram's stain & - & - & - & - & - & - \\
\hline Motility & + & + & + & + & + & + \\
\hline Flagellation & $\mathbf{M}$ & $\mathbf{M}$ & $\mathbf{P}$ & $\mathbf{M}$ & $\mathbf{M}$ & $\mathbf{M}$ \\
\hline Oxidase test & + & + & + & + & + & + \\
\hline Hugh-Leifson & NC & NC & $\mathbf{F}$ & $\mathrm{NC}$ & $\mathbf{F}$ & $\mathbf{F}$ \\
\hline $0 / 129$ & - & - & - & - & + & + \\
\hline Arginine test & + & + & + & + & + & + \\
\hline Gelatine hydrolysis & + & + & + & + & + & + \\
\hline $\mathrm{NaCl}$ tolerance $7 \%$ & + & + & + & + & + & + \\
\hline Heat resistance $40^{\circ} \mathrm{C}$ & + & + & + & + & + & + \\
\hline$" \quad 45^{\circ} \mathrm{C}$ & - & + & + & + & - & - \\
\hline $50^{\circ} \mathrm{C}$ & - & - & - & - & - & - \\
\hline
\end{tabular}

+ : positive in Gram's stain, motile in motility, positive in oxidase test, inhibitive to $0 / 129$, positive in deaminase test, hydrolytic in gelatin, tolerant to $\mathrm{NaCl} 7 \%$, survival on the temperatures, $40^{\circ} \mathrm{C}, 45^{\circ} \mathrm{C}, 50^{\circ} \mathrm{C}$.

M: monotrichous or multitrichous, P: peritrichous, F: fermentative, NC: no change.

Table 2. Growth behavior on five definite media.

\begin{tabular}{c|cccccc}
\hline \hline Strain & A-4 & A-6 & B-1 & B-4 & B-5 & B-8 \\
\hline Medium* & - & - & - & - & - & - \\
A & - & - & + & - & - & - \\
B & - & + & + & - & - & - \\
C & + & + & + & + & - & - \\
E & + & + & + & + & + & + \\
\hline Type & M & H & H & M & M & M \\
\hline
\end{tabular}

+: Growth, - : No growth, H: Halophilic type , M: Marine type.

* Preparation of media.

\begin{tabular}{c|ccl}
\hline Medium & Polypepton & Yeast ext. & Diluent \\
\hline A & $0.05 \%$ & $0.01 \%$ & Water \\
B & $"$ & $"$ & $0.5 \% \mathrm{NaCl}$ sol. \\
C & $"$ &, & $3 \% \mathrm{NaCl}$ sol. \\
D & $"$ &, & $1 / 6 \mathrm{~A}$. S.W. \\
E & $"$ &, & A.S.W. \\
\hline
\end{tabular}

the other two chemicals. Adsorption rate demonstrated that only B-8p was poorer than the other five phages, the fives being ranged from 80 to 90 per cent. At burst size measurement, $A-4 p$ was the largest, followed by A-6p, B-4p, B-5p, B-8p, and B-1p. Latent periods of them were from 30 to 50 minutes in all bacteriophages used (Table 3).

Comparing the heat resistance between the host bacteria and the bacteriophages, as 
Table 3. Characteristics of bacteriophages.

\begin{tabular}{|c|c|c|c|c|c|c|}
\hline Bacteriophage & $A-4 p$ & $A-6 p$ & $B-1 p$ & $B-4 p$ & B-5p & B-8p \\
\hline $\begin{array}{l}\text { *Phage count } \\
\text { passed through } \\
\text { Milipore }(0.45 \mu)\end{array}$ & $3 \times 10^{6}$ & $0.5 \times 10^{6}$ & $48 \times 10^{6}$ & $68 \times 10^{8}$ & $92 \times 10^{6}$ & $4 \times 10^{6}$ \\
\hline \multicolumn{7}{|l|}{ *Chemicals resistance } \\
\hline $10 \%$ Chloroform & $64 \times 10^{6}$ & $52 \times 10^{6}$ & $58 \times 10^{6}$ & $34 \times 10^{6}$ & $92 \times 10^{6}$ & $62 \times 10^{6}$ \\
\hline $0.5 \%$ Phenol & $76 \times 10^{6}$ & $40 \times 10^{6}$ & $125 \times 10^{6}$ & $52 \times 10^{6}$ & $18 \times 10^{6}$ & $28 \times 10^{6}$ \\
\hline $0.5 \%$ Formaldehyde & 6100 & 348 & 4 & 1002 & 889 & 362 \\
\hline \multicolumn{7}{|l|}{${ }^{*}$ Heat resistance } \\
\hline $60^{\circ} \mathrm{C}$ & + & + & + & + & + & + \\
\hline $70^{\circ} \mathrm{C}$ & + & - & + & - & + & - \\
\hline *Adsorption (\%) & 88.4 & 95.5 & 88.0 & 96.4 & 81.7 & 68.8 \\
\hline Burst size & 173 & 125 & 82 & 113 & 87 & 85 \\
\hline Latent period (min) & 50 & 40 & 50 & 30 & 40 & 30 \\
\hline
\end{tabular}

* In these experiments, the bacteriophages used were prepared for definite concentration $10^{8} \mathrm{pfu} / \mathrm{ml}$.
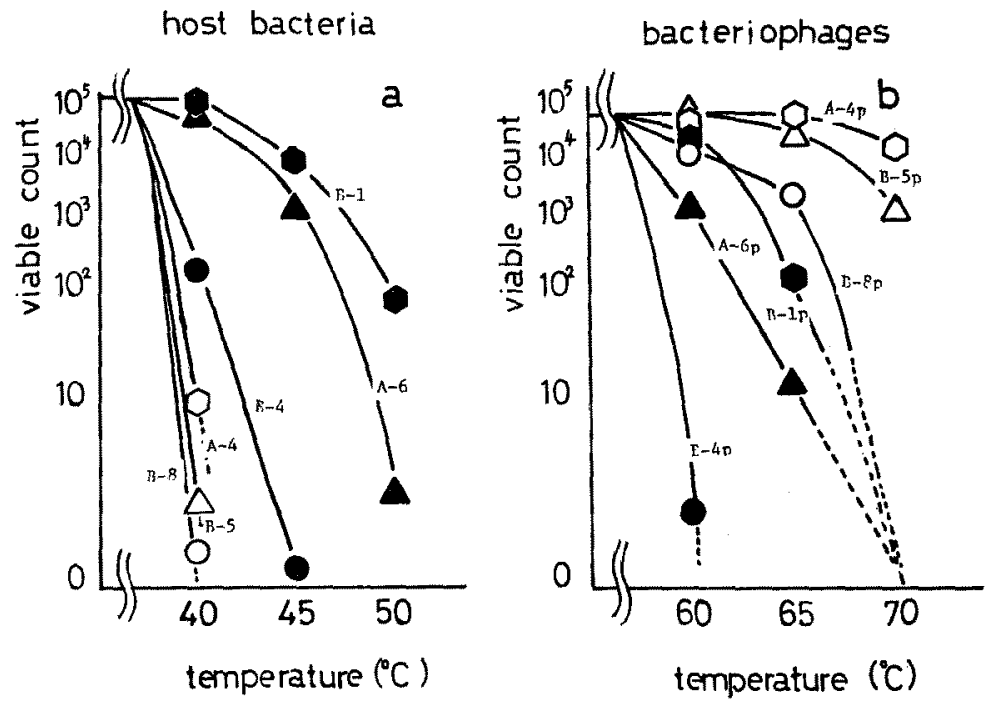

Fig. 4. Heat resistance of both host bacteria and bacteriophages.

shown in Fig. 4, that of bacteriophages was usually higher than that of the host bacteria. That is, the host bacteria A-4, B-4, B-5 and B-8, all of marine type, were killed at $45^{\circ} \mathrm{C}$, while B-1 and A-6 alive. On the other hand, three bacteriophages A-6p, B-1p, B-8p, and $B-4 p$ were killed at $70^{\circ} \mathrm{C}$, while $\mathrm{A}-4 \mathrm{p}$ and $\mathrm{B}-5 \mathrm{p}$ alive at $70^{\circ} \mathrm{C}$. Incidentally, the stability to the hypotonic solution of diluted artificial sea water was observable in the bacteriophages, but under similar dilution the host bacteria were killed, only exception being observed in A-6p (Fig. 5). 

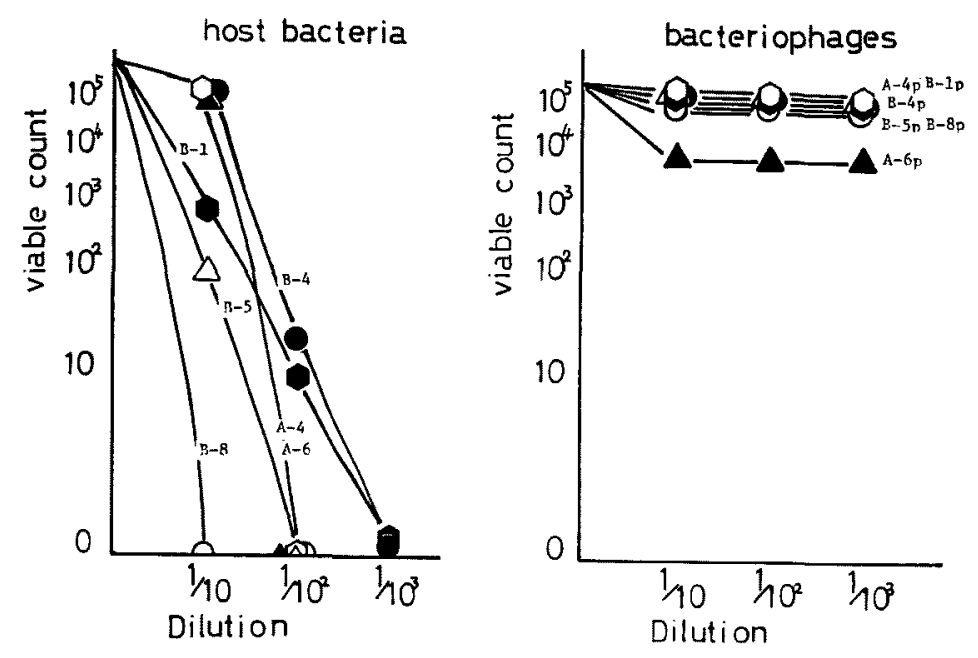

Fig. 5. Stability of both host bacteria and bacteriophages in diluted ASW.

Electron microscopic views were shown in Plate 1. In this plate, both sheath and spikes were observed in A-6p and spikes were in B-1p, B-5p, and B-8p respectively. Fibers could not be observed in all bacteriophages.

\section{Acknowledgement}

We acknowledge the good discussion of Dr. HIDAKA, and the exellent techinical assistnace of Mr. HIRAKAwA in operation of the electron microscope. This study was partly supported by a grant from the Ministry of Education of Japan.

\section{References}

1) A. E. KRiss and E. A. Rukina: Doklady Akad. Nauk SSSR, 57, 833-836 (1947).

2) R. SPENCER: Nature, 175, 160-161 (1955).

3) P. K. Chen, V. Citarella, O. Salazarand, and R. R. Colwell: J. Bacteriolog., 91, 1136-1139 (1966).

4) R. M. Johnson: J. Arizona Aca. Scie., 5, 28-33 (1968).

5) A. F. Valentine, P. K. Chen, R. R. Colwell, and G. B. Chapman; J. Bacteriolog., 91, 819-822 (1966).

6) M. H. Adams: in "Bacteriophages" Interscience, New York (1959).

7) N. BAIN and J. M. SHEwAN: in "Identification methods for microbiologist II" (B. M. GibBs and D. A. Shapton ed.), Vol. 2 part B, 79-84, Academic Press London and New York (1968).

8) T. HidAKa: Mem. Fac. Fish., Kagoshima Univ., 14, 127-180 (1965).

9) E. Billing: in "Methods in Microbiology" (J.R. Noris and D. W. Ribions ed.), Vol, 3B, 313 -329, Academic Press London and New York (1969). 


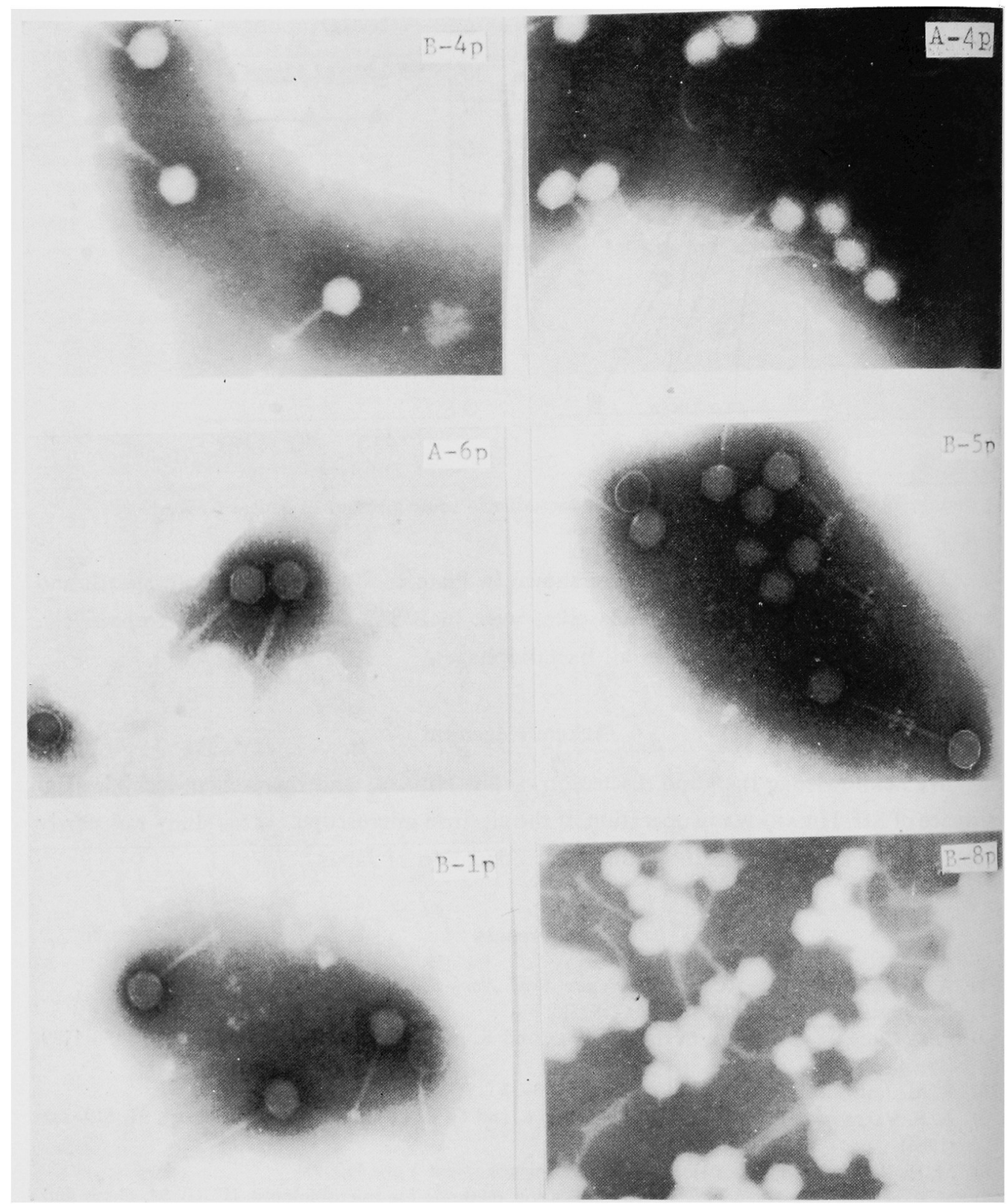

Plate 1. All bacteriophages are stained with phosphotangstic acid $(\times 100,000)$. 